\title{
Migrantkirker. Fra grænseflade til kerne i den danske religionsmodel
}

\author{
ASTRID KRABBE TROLLE
}

ENGLISH ABSTRACT: Christian migrant churches have been a part of the borderland of the Danish model of religion for a long time, but the state and the Danish folk church are opening up for migrant churches to become a part of the Danish folk church through valgmenighedsloven (law on free congregations). Some migrant churches thereby move from the borderland to the core of the Danish model of religion. This movement, however, is not without conflict as several migrant churches challenge the conventional and Westphalian way of conceptualising religion. I use Peter Beyer's theory of Post-Westphalian religion to shed light on the possible borders between the migrant churches and the Danish folk church.

DANSK RESUMÉ: Kristne migrantkirker har længe været en del af den danske religionsmodels grænseflade, men staten og folkekirken er ved at åbne op for, at de nyere migrantkirker kan blive en del af folkekirken via valgmenighedsloven. Dermed bevæger nogle migrantkirker sig fra religionsmodellens grænseflade til at blive en del af modellens kerne. Denne bevxgelse er dog ikke uden konflikter, da flere migrantkirker udfordrer den gængse og westfalske måde at tænke religion på. Artiklen gør brug af Peter Beyers teori om postwestfalsk religion til at belyse de mulige grænser mellem migrantkirkerne og folkekirken.

KEYWORDS: Migrant churches; the Danish folk church; integration; Jesus Is Lord; Church of Love; Post-Westphalian religion

Denne artikel beskæftiger sig med, hvordan kristne migrantkirker placerer sig og placeres i den danske religionsmodel, som Christoffersen et al. har beskrevet i Fremtidens danske religionsmodel (Christoffersen et al. 2012, 14). Som minoritetskirker er migrantkirkerne placeret i modellens grænseflade, men nogle migrantkirker er ved at bevæge sig fra grænsefladen ind i modellens folkekirkelige kerne i kraft af valgmenig- 
hedsloven (2014). Denne bevægelse fra grænseflade til kerne er primært faciliteret af to aktører: den danske stat og den danske folkekirke, da begge institutioner har en interesse $\mathrm{i}$ at integrere kristne migranter og deres kirker i de kirkelige og nationale strukturer. ${ }^{1}$ Selvom folkekirken ikke altid handler som én aktør men snarere som et væld af forskellige initiativer inden for samme organisation, kan det give mening at se folkekirken som samlet aktør ud fra dets placering som majoritetsreligion i den danske religionsmodel. Artiklen arbejder altså med migrantkirker ud fra et majoritetsperspektiv. Den undersøgte grænseflade er her især mellem de kristne migrantkirker og folkekirken.

Artiklen gør brug af den tysk-canadiske religionssociolog Peter Beyers teori om, hvordan religionssystemet i sin postwestfalske form modelleres over andre samfundssystemer, eksempelvis det økonomiske system (Beyer 2012, 114). Den beyerske ramme peger på, hvordan nogle af migrantkirkernes globale markedsgørelse både udvider religionsmodellen men også trækker grænser overfor den nationale majoritetskirke, her folkekirken. I det følgende vil jeg først diskutere begrebet migrantkirke og dets brugbarhed som analytisk kategori i den danske religionsmodel. Dernæst viser artiklen, hvordan både stat og folkekirke arbejder på at integrere kristne migranter i de eksisterende kirkelige strukturer gennem flere eksempler på integrationsprojekter med migrantkirker som målgruppe. I den forbindelse præsenterer jeg to eksempler på, hvordan migrantkirkerne Church of Love og Jesus Is Lord på hver sin måde udfordrer folkekirken og den danske religionsmodels grænser.

Church of Love blev i oktober 2014 en del af folkekirken som migrantvalgmenighed, mens kirken Jesus Is Lord repræsenterer en religiøs organisation, der vil blive ved med at befinde sig i den danske religionsmodels grænseflade. Begge kirker nuancerer majoritetsaktørernes placering af migrantkirker i bevægelse ind mod religionsmodellens kerne.

\section{Migrantkirker som begreb og analyseenhed}

I artiklen bruger jeg begrebet migrantkirke om de kristne migranters organisationsform. Det gør jeg, fordi mange migranter selv identificerer sig som kirke, og fordi migrantkirke er det mest benyttede begreb i en europæisk kontekst (Währisch-Oblau 2009, 35). I det kirkelige miljø i Danmark henviser man dog for det meste til migrantmenigheder, ikke til kirker. ${ }^{2}$ Forklaringen herfor kan findes i, at menigheder er et elastisk begreb i kirkeligt regi. Derfor taler man både om funktionsmenigheder og profilmenigheder inden for folkekirken (Iversen 2013, 60). Migrationsforskningen arbejder også med betegnelsen de facto congregationalism, der kort fortalt betyder, at migranters religion gennemgår en strukturel tilpasning (structural adaption) til me-

1 Jeg benytter udtrykket migranter i artiklen for at fremhæve migranternes bevægelse frem for deres ind(immigrant) eller udrejse (emigrant) (Castles \& Miller 2003).

2 Med kirkeligt miljø mener jeg de danske kirker, der arbejder med kristne migranter. 
nighedsformen i mødet med det protestantiske værtsland (Ebaugh 2003, 233; Kivisto 2014, 1; Martikainen 2009, 177; Warner 1998).

Når det kirkelige miljø benævner migrantkirker menigheder, kan man også forstå betegnelsen som en positionering i den danske religionsmodel. Menighed bliver her en underkategori til kirke, som vi f.eks. ser det i nedenstående modstilling mellem danske kirker og nye migrantmenigheder:

Her er det vigtigt at de nye migrantmenigheder og de danske kirker lærer af hinanden, bliver inspireret af hinanden og finder ud af at vandre sammen, så relationen ikke ender i konkurrence men som samarbejde ... Fælles for migrantmenighederne gælder det, at de ønsker at se sig som et supplement til de eksisterende danske kirker og ikke som konkurrenter (Lund 2009).

Citatet er fra en kortlægning af de eksisterende migrantkirker i Danmark offentliggjort i 2009, hvor en bred sammenslutning af forskellige kirker med folkekirken i spidsen var gået sammen om at indhente information om de nye kristne migranter $\mathrm{i}$ landet. ${ }^{3}$ Nedenfor går artiklen mere i dybden med den pågældende undersøgelse, men i denne sammenhæng er det vigtigt at bemærke den eksplicitte modstilling mellem etablerede kirker og nye migrantmenigheder. Tonen i ovennævnte citat er meget positivt stillet overfor migrantkirkerne, der, som forfatteren skriver, snarere skal ses som et supplement til de eksisterende tilbud end som en egentlig konkurrent på det religiøse marked. Langt hellere end konkurrenter er de danske kirker interesserede $\mathrm{i}$ at indlemme de nye migrantkirker i de eksisterende kirker eller at have migrantkirker som et forum for nyligt ankomne migranter. Dermed afspejler termen migrantmenigheder majoritetskirkens kategorisering af nytilkomne minoritetskirker. Benævnelsen migrantmenighed får karakter af noget foranderligt, både fordi nogle migranter rejser videre, men også fordi migrantmenighederne potentielt kan bevæge sig længere ind i den danske religionsmodel og indgå i dens kerne, her forstået som folkekirken.

I den nævnte kortlægning af de kristne migrantkirker lød definitionen af migrantmenigheder: "mindst 10 personer der jævnligt mødes og fejrer kristen gudstjeneste/messe på et andet sprog end dansk ved en præst eller leder, der ikke er etnisk dansk" (Krarup de Medeiros 2009). Jeg vil fremover benytte denne definition til begrebet migrantkirke. Selvom man altid skal være varsom med at bruge samlebetegnelser, der afspejler majoritetssamfundets italesættelse af minoriteter, kan det $\mathrm{i}$ denne sammenhæng være frugtbart at benytte migrantkirker som analytisk kategori i den danske religionsmodel på grund af de kristne migranters reception i Danmark. Her bliver majoritetsaktører som staten og folkekirken vigtige, fordi de er med til at påvirke de kristne migranters placering og kategorisering inden for modellen.

3 Kortlægningen var et samarbejde mellem Areopagos, Dansk Missionsråd, Danske Kirkers Råd, Den katolske Kirke, Grundtvigsk Forum, Indre Mission, Kirkefondet, Kirkeligt Centrum, Landsforeningen af Menighedsråd og Tværkulturelt Center (Migrantmenigheder 2009). 


\section{Westfalske og postwestfalske religionskategorier}

Ifølge den tyske teolog Claudia Währisch-Oblau har nye kristne migranter og deres kirker altid været marginaliserede på det europæiske kontinent, fordi det europæiske kristendomsbegreb er så bundet til etnisk og national identitet (Währisch-Oblau 2009 , 5). Denne forbindelse mellem kristendom og nationalitet/etnicitet har sine teologiske rødder i reformationens idé om, at kristendom bedst forstås gennem ens modersmål, og sine historiske rødder i en række sammenkædninger mellem nationalstat og én privilegeret majoritetskirke fra 1600tallet og frem (ibid, 5; Blückert 2000, 311). Religionssociologen Peter Beyer argumenterer langs samme linjer for, at nationalstat og majoritetskirke siden den westfalske fred i 1648 har modelleret sig over hinandens funktionssystemer, sådan at både nationalstat/det politiske system og majoritetskirke/det religiøse system opererer ud fra et helhedsprincip vedrørende statsborgerskab og kirkemedlemskab (Beyer 2012, 115). Begge medlemskaber er eksklusive, og det har den konsekvens, at samfundet har svært ved at acceptere dobbelt medlemskab af religioner eller nationer. ${ }^{4}$ Dette westfalske religionsbegreb tænker altså i medlemskab og eksklusiv tilknytning til én kirke. Samtidig med at én religion fik privilegeret status, blev minoritetsreligioner som kategori også defineret som religioner, der ikke er forbundet til den rådende magt. Som følge af denne religionsforståelse har religiøse migranter i Europa ofte organiseret sig i nationalt eller etnisk forankrede minoritetskirker (Währisch-Oblau 2009, 5). Derudover fungerer det etniske religiøse fællesskab også ofte som en socialt integrerende institution for især den første generation af immigranter (Connor 2014, 71; Hirschmann 2004; Ebaugh 2003, 232). Til gengæld er migranterne i mindre grad tilknyttet majoritetskirken i værtslandet, i Danmarks tilfælde folkekirken. Währisch-Oblau problematiserer den klassiske inddeling efter nationalitet og etnicitet, fordi mange migrantkirker netop rækker ud over disse skillelinjer i deres teologi, hvor målet er at omvende folk til den pågældende kirkes globale kristendom. Ud over teologiske nuanceringer bør den europæiske og westfalske idé om det eksklusive nationale tilhørsforhold heller ikke tages for givet. Langt de fleste migranter orienterer sig relativt uproblematisk mod flere nationale og regionale kontekster, hvilket gør eksklusiv national identitet mindre brugbar som analytisk redskab. Beyer peger på, at religionen i stedet for den gensidige modellering over nationalstaten finder nye former ved at modellere sig over andre funktionssystemer såsom mediesystemet og det kapitalistiske økonomiske system (Beyer 2012, 119). Konkret betyder dette blik på religion, at man åbner op for at analysere religion som eksempelvis et markedsorienteret målbart produkt, der opererer efter samme principper som det økonomiske system. Nedenfor vil jeg illustrere religionens mulige modellering over det økonomiske system i den filippinske migrantkirke Jesus Is Lord.

4 Dog har der historisk set altid været religiøse modbevægelser og alternativer til den westfalske kirke-stat model (Beyer 2012, 118). 


\section{Kirkelige aktører i den danske religionsmodel}

Billedet af den muslimske migrant som religiøs 'anden' har længe og i en nutidig kontekst især siden 11. september 2001 præget både medierne og forskningen (Asad 2001; Casanova 2010; Jacobsen 2008). I forhold til denne gruppe af religiøse migranter, har de kristne migranter levet en så godt som usynlig tilværelse i offentlighedens bevidsthed. Derfor er langt de fleste undersøgelser af kristne migranter i Danmark foretaget af danske kirkelige organisationer med intentionen om at informere det kirkelige miljø om migrantkirker i et integrations- og samarbejdsperspektiv. ${ }^{5}$ Eksempler på dette er projekterne Folkekirken og migrantmenigheder og Folkekirkens Migrantarbejde, som begge forsøger at bevæge migrantkirkernes position i den danske religionsmodel.

\section{Folkekirken og migrantmenigheder}

I 2009 offentliggjorde Folkekirkens mellemkirkelige Råd og paraplyorganisationen Kirkernes Integrationstjeneste en rapport med tilhørende hjemmeside om migrantkirkerne i Danmark (Migrantmenigheder 2009a). ${ }^{6}$ Publikationen kortlægger alle såkaldte migrantmenigheder med henblik på 1) at give viden om de kristne migranters antal og nationale oprindelse og 2) at skabe kontakt mellem de kristne migrantkirker og den danske folkekirke (Arendt 2009). Initiativet til dette kortlægningsprojekt kom fra de danske biskopper i 2006 med økonomisk støtte fra bl.a. integrationsministeriet, og det kan derfor ses som en informationsindsamling med både folkekirke og stat som aktører. Kortlægningen af migrantkirker arbejdede ud fra ovennævnte definition på en migrantmenighed og samler en lang række meget forskellige grupperinger: både den grønlandske menighed i København, der teknisk set både består af danske statsborgere og medlemmer af folkekirken, de forskellige sproggrupper inden for den katolske kirke samt mere etnisk definerede kirker som eksempelvis Copenhagen Chinese Christian Mandarin Church. Det er med andre ord svært at finde en fællesnævner for alle de kortlagte kirker med undtagelse af deres kristne profil og fremmede sprog. Kortlægningen bygger ifølge projektets hjemmeside på spørgeskemaer, besøg og interviews i migrantkirkerne (Krarup de Medeiros 2009). Et estimat af antallet af migrantmenigheder lyder på 212 ultimo 2008 (Sørensen 2009), mens tallet ved sidste optælling i april 2014 var på 219 (Tværkulturelt Center 2014). Det er som altid kompliceret at finde nøjagtige tal, da mange kirker ikke er registreret eller stats-

5 Der er dog undtagelser, eksempelvis Hvithamar 2007 og Borup 2011.

6 Kirkernes Integrationstjeneste blev etableret i 2003 som et fælleskirkeligt organ til koordinering af de danske kirkers integrationsindsats overfor de nye kristne migrantkirker. Organisationen samarbejder med de danske frikirker, den danske folkekirke og den katolske kirke i Danmark (Kirkernes Integrationstjeneste 2014). Folkekirkens mellemkirkelige Råd består af tretten medlemmer, udpeget af Danmarks ti stifter og Grønland samt to biskopper udpeget af kirkeministeren. Rådet er rettet mod det folkekirkelige arbejde med kirker uden for folkekirken og i udlandet (Folkekirkens mellemkirkelige Råd 2014). 
godkendte trossamfund. Ligeledes er det også forskelligt, hvor lang tid det kan tage de enkelte migrantkirker at søge om godkendelse som trossamfund i Danmark (Nielsen 2014, 8). Ud af de 212 migrantmenigheder registreret på projektets hjemmeside i 2009 var 23 godkendte trossamfund (Familiestyrelsen 2014). Men det er svært at sammenligne tallene, da Folkekirken og migrantmenigheders kortlægning ikke er bundet op på offentlige registre. Projektet er dog heller ikke interesseret i migrantkirkernes offentlige registrering, da hovedformålet er at give det kirkelige miljø i Danmark information og redskaber til integration af og samarbejde med migrantkirker. Projektet klassificerer migrantkirkerne i tre overordnede kategorier: de historiske migrantkirker, de etniske kirker og de internationale kirker, der ofte er engelsktalende (Krarup de Medeiros 2009). I den danske religionsmodel repræsenterer alle kategorier et transnationalt udsyn med glokal religiøs praksis (Robertson 1995). Kortlægningen i 2009 er vigtig, fordi den ofte bruges som kilde i medieindlæg om kristne migranter, men også fordi den viser en interesse fra de danske kirkelige aktører overfor de nye migrantkirker. Det stadigt igangværende kirkelige arbejde med at registrere og samarbejde med migrantkirker kan i denne sammenhæng forstås som en strategi fra nogle dele af folkekirken til at bevæge de nye kristne migrantkirker ind i den danske religionsmodels kerne.

\section{Stat og folkekirke som aktører i den danske religionsmodel}

Både stat og folkekirke arbejder for at integrere kristne migranter i den danske religionsmodel og den danske nationalstat men med forskellige hensyn. I et grænsefladeperspektiv er det primært de teologiske grænser, der optager repræsentanter for folkekirken, mens de statslige initiativer er målrettet national integration. Dog forbinder begge aktører vellykket integration af migrantkirker med kristent samarbejde. Ved offentliggørelsen af ovennævnte rapport fra projektet Folkekirken og migrantmenigheder i 2009 var både nye migrantkirker, etablerede danske minoritetskirker, medlemmer af folketinget og folkekirken repræsenteret. Kirkeordfører for Det Konservative Folkeparti Charlotte Dyremose, MF, gav ved denne anledning sit bud på, hvorfor kortlægningen af kristne migranter havde betydning. Her i forbindelse med konvertitter til kristendommen:

Og når det nu fremgår af undersøgelsen, at der faktisk er mange konvertitter bland de mennesker, der kommer hertil med en anden tro end den kristne, så er der jo en særlig opgave med at sikre, at de kan finde et kristent fællesskab, der får dem til at føle sig hjemme. Det gør ikke så meget, om det er indenfor Folkekirkens rammer eller i et andet regi. Det væsentlige må igen være det overordnede kristne fællesskab. Vi må som kristne og kirke vise de åbne døre i et demokratisk og kristent land (Dyremose 2009).

Dyremose taler her om integration ud fra en sammenkædning af kristendom og demokrati, hvor den overordnede kristne ramme er vigtigere end den specifikt fol- 
kekirkelige. Kristne migranter og konvertitter skal integreres ind i et kristent fællesskab i Danmark, hvilket er helt i overensstemmelse med de folkekirkelige initiativer. Men hvor danske kirker er interesserede i et kirkeligt fællesskab, er det nationale kristne fællesskab for Dyremose mere betydningsbærende. Kristendom bliver her en symbolsk national markør frem for et spørgsmål om konfession. Den statslige aktør i dette tilfælde er integrationsministeriet, der har givet økonomisk støtte til Folkekirken og migrantmenigheders kortlægning, men Dyremose viser os dertil de mulige bevæggrunde for at bevæge de kristne migranter ind i den danske religionsmodel. Kristne migrantkirker bør integreres ind i det kristne nationale fællesskab.

Den samme bevægelse mod større samarbejde mellem folkekirke og migrantkirker kan man finde i en lovændring, som den tidligere minister for Ligestilling og Kirke (nu kirkeministeriet) Manu Sareen fremsatte i 2012. Lovændringen blev vedtaget i marts 2013 og har bl.a. til hensigt at åbne folkekirken op for brug af andre kristne trossamfund end evangelisk-lutherske. Ændringen var også støttet af Landsforeningen af Menighedsråd (Landsforeningen af Menighedsråd 2014). Nedenfor begrundes lovforslaget i 2012:

...formålet med lovforslaget [er] at lempe adgangen for evangelisk-lutherske frimenigheders faste brug af folkekirkens kirker, ligesom der gives mulighed for, at andre kristne trossamfund også kan få kirken overladt til fast brug. Samtidig gøres det muligt, at medlemmer af evangelisk-lutherske frimenigheder og andre kristne trossamfund kan få kirken overladt til vielse ved en præst i det pågældende trossamfund (Sareen 2012).

Det konkrete møde mellem de kristne migrantkirker og de etablerede danske kirker sker ofte i forbindelse med lån af kirkelokaler til gudstjenester og andre kirkelige aktiviteter. Migrantkirker har et behov for at låne lokaler til deres religiøse praksis og andre sociale begivenheder, da de sjældent har deres egne kirkebygninger. Både frikirker og den lokale folkekirke har som oftest en kirkebygning med tilhørende lokaler, som ikke er i brug alle ugens dage. For migrantkirker betyder denne lovændring, at de har en mere direkte adgang til folkekirkens bygninger, og at de også får mulighed for at udføre vielser i bygningerne. Tidligere har brugen været begrænset til gudstjenester, begravelse og i sjældne tilfælde vielse, hvis det enkelte menighedsråd siger god for det. Rent praktisk er både gudstjeneste, begravelse og måske fremover også vielser i folkekirkelige bygninger afhængig af kirkens præst, sognets menighedsråd og i sidste instans stiftets biskop. ${ }^{7}$ Migrantkirker og etablerede kirker har landet over et samarbejde i forbindelse med kirkelokaler, men de folkekirkelige bygninger er bundet til lovgivning vedrørende bestyrelse og brug af folkekirkens kirker. Derfor er det muligt for staten at regulere dele af samarbejdet og dermed grænsefladen mellem migrantkirke og folkekirke, selvom man i det enkelte menighedsråd har

7 Jf. Hans Raun Iversens bidrag til dette temanummer samt Bekendtgørelse af lov om bestyrelse og brug af folkekirkens kirker mm. 2014 
mulighed for at afvise et samarbejde med en migrantkirke. De statslige aktører er altså i høj grad til stede i integrationsinitiativer med migrantkirker som emne.

\section{De teologiske grænser}

En potentiel teologisk grænsedragning i den ønskede integration af de kristne migrantkirker i folkekirken kan findes i synet på mission. Mange migrantkirker arbejder med et missionalt perspektiv i deres religiøse praksis. Det vil sige, at Danmark gerne skal omvendes til den rette tro efter en lang periode med sekularisering på forskellige niveauer i samfundet. Dette fænomen kalder den nigerianske religionshistoriker Afe Adogame 'reverse mission' eller omvendt mission (Adogame 2010, 513). Omvendt mission refererer til de missionsbevægelser, der i øjeblikket arbejder i Europa og USA som missionerende migrantkirker. Ideen er her, at de tidligere koloniserede og kristnede befolkninger i det globale syd nu vender missionen om og etablerer kirker i den vestlige del af verden med det mål at give det kristne budskab tilbage til de tidligere kristne nationer (Adogame \& Shankar 2013, 1). Missionsaspektet kan især findes i de internationale kirker, som er direkte møntet på at omvende forskellige etniske grupper. ${ }^{8}$ Her bliver den danske religionsmodel udfordret i kraft af den transnationale dimension af en ofte karismatisk evangelisk kristendom. Det missionale perspektiv har en betydning for forholdet til de eksisterende danske kirker herunder folkekirken. Det blev bl.a. tydeligt i debatten omkring migrant- og sognepræst Massoud Fouroozandehs praksis med at omvende muslimer til kristendom men ikke til folkekirke, der kan ses som et led i projektet Folkekirkens Migrantarbejde.

\section{Folkekirkens Migrantarbejde}

Den iranskfødte migrantkirkepræst for Church of Love, Massoud Fouroozandeh, blev i 2011 ordineret som sognepræst ved Sankt Hans Sogn i Fyens Stift som en del af det treårige projekt Folkekirkens Migrantarbejde. ${ }^{9}$ Projektets formål var ifølge dets vedtægter at bidrage til en integrationsproces mellem migrantkirker og folkekirke:

2. At skabe mulighed for samtale og gensidig tillid mellem migrantmenighederne og folkekirken og således folkeligt og kirkeligt bidrage til en integrationsproces.

3. At bane vejen teologisk og juridisk for, at migrantmenigheder kan få mulighed for at få en tilknytning til folkekirken, herunder muligheden for at danne valgmenigheder.

8 Dog har en ny undersøgelse vist, at de missionerende migrantkirker primært omvender andre migranter med samme etniske orientering (Koning 2013, 341).

9 Projektet blev lanceret af Fyens Stift og Edith \& Godtfred Kirk Christiansens Fond. Det blev ledet af en bestyrelse bestående af biskoppen over Fyens Stift (Drejergaard), domprovsten for Skt. Knuds provsti, en repræsentant for Edith \& Gotfred Kirk Christiansens Fond samt en repræsentant for Fouroozandehs menighed (Vedtægt for Folkekirkens Migrantarbejde 2011). 
Her får vi præsenteret, hvordan folkekirken, her repræsenteret ved Fyens Stift, vil integrere de kristne migrantkirker: ved muligheden for at danne valgmenigheder. Valgmenigheder er tilknyttet folkekirken men er organisatorisk og økonomisk uafhængige. Det vil sige, at valgmenighedens medlemmer er medlemmer af folkekirken men ikke forpligtet til at betale kirkeskat. Til gengæld er valgmenigheden tilknyttet folkekirken i teologisk henseende, da menigheden og dens præst er underlagt kirkeligt tilsyn på samme måde som andre menigheder inden for folkekirken (valgmenighedsloven 2014). Fouroozandeh som person spiller her en central rolle for integrationsprocessen i projekt Folkekirkens Migrantarbejde, fordi han som både migrant- og sognepræst skal agere bindeled mellem migrantkirkerne og folkekirken. Hans person inkarnerer så at sige grænsen mellem migrantkirke og folkekirke, og det er også med dette i sigte, at Fouroozandeh blev ansat som sognepræst. Nedenfor er et uddrag af ordinationstalen for Fouroozandeh holdt af biskop Kresten Drejergaard:

For når jeg i dag ordinerer dig, så giver jeg dig dermed autorisation til at fungere i den evangelisk-lutherske kirke, som hos os er den danske folkekirke. Men faktisk har du jo selv været både pave, biskop og præst i lang tid i Church of Love, og det skal du også fortsat være, samtidig med at du har autorisationen til at være præst i den danske folkekirke ... I fællesskab skal vi til at udforske friheden i folkekirken og grænserne for fol-

kekirken (Drejergaard 2011a).

I talen understreger Drejergaard, at Fouroozandeh i kraft af sin dobbelte rolle skal medvirke til at udforske grænserne for folkekirken. Folkekirkens Migrantarbejde skal altså udvide og udfordre de folkekirkelige grænser ved at integrere valgmenigheder med anden etnisk baggrund end dansk. Den iranske kirke Church of Love bliver folkekirkens første valgmenighed med anden etnisk profil. Dermed åbner projektet også op for det transnationale perspektiv i den danske religionsmodels folkekirkelige kerne og med det også nye måder at kombinere etnicitet, nationalitet og kristendom på inden for den folkekirkelige ramme. Biskop Drejergaard har i en anden sammenhæng udtalt, at arbejdet med at integrere migrantmenigheder i hele folkekirken er vigtigt for folkekirkens profil: "Jeg mener, at et sådant projekt også er frugtbart for folkekirken, som nødig skulle ende som en hjemstavnsforening for etniske danskere" (Drejergaard 2011b). Men denne åbning af folkekirken blev for meget for de andre danske biskopper.

\section{Teologiske grænser: dåbspraksis og medlemskab}

I december 2013 skabte migrant- og sognepræst Massoud Fouroozandeh debat i det folkekirkelige miljø i Danmark som følge af sin dåbspraksis med at døbe muslimer til kristendom i Church of Love men ikke til den danske folkekirke. Som vi tidligere har set var en del af projektet Folkekirkens migrantarbejde at give både Fouroozandeh og Church of Love dobbelte roller for at fremme migrantkirkers integration ind i folke- 
kirken som valgmenigheder. Fouroozandeh havde i denne forbindelse stor succes med at omvende iranske muslimer til kristendom, men hans missionale virksomhed faldt udenfor de folkekirkelige rammer, da dåben ikke var direkte forbundet til medlemskab i folkekirken. Som landets biskopper udtrykte det i en fælles udtalelse til Kristeligt Dagblad 7. december 2013:

Som folkekirkepræst skal Massoud være medlem af folkekirken, og som folkekirkepræst står han i alle aspekter af sin præstelige virksomhed under tilsyn af sin biskop. En folkekirkepræst kan ikke på én gang være præst i folkekirken og i en frikirke, der står uden for folkekirken, ligesom en folkekirkepræst ikke kan døbe nogle personer til folkekirkeligt medlemskab og andre til et frikirkeligt medlemskab (Kristeligt Dagblad $7 / 12 / 13)$

I denne udtalelse går de danske biskopper samlet ud i offentligheden til forsvar for det eksklusive medlemskab af folkekirken og en dåbspraksis, der forbinder dåb med medlemskab af en bestemt kirke. Debatten var stærk internt i det folkekirkelige miljø, men den kan også ses i lyset af det westfalske religionsbegreb. I citatet ovenfor sår folkekirkens top tvivl om, hvorvidt det er muligt for Fouroozandeh både at være præst i Church of Love og i folkekirken. Fouroozandeh har altså udfordret folkekirkens westfalske religionsforståelse ved sin dobbelte præsterolle, men også ved at arbejde med flere kategorier af medlemskab. I forbindelse med dåbssagen udtalte Fouroozandeh selv, at han anser Church of Love som en gummibåd, der hjælper de iranske medlemmer til på sigt at blive medlemmer af den danske folkekirke (Berlingske Tidende 2013). Medlemskabet er altså ikke på samme måde eksklusivt, som det ellers forventes i den folkekirkelige og westfalske model. I den danske religionsmodel bruger Fouroozandeh postwestfalske kategorier i sit fokus på universel - og ikke national - kristendom, men forsøget afvises i mødet med religionsmodellens folkekirkelige kerne. Grænsefladen mellem folkekirke og migrantkirke tegnes skarpt op i denne sag, og stiller spørgsmålstegn ved den fremtidige bevægelse af migrantkirker ind mod modellens kerne. ${ }^{10}$ Udgangen på dåbssagen er i skrivende stund, at Church of Love i oktober 2014 blev godkendt som valgmenighed af kirkeministeriet. Kirkens medlemmer bliver dermed også døbt ind i folkekirken.

\section{Jesus Is Lord i modellens grænseflade}

Ligesom Fouroozandeh har udfordret den danske religionsmodels kerne ved at arbejde med elastiske former for medlemskab og religiøs praksis, udvider migrantkirkerne som nævnt vores kategorier ved deres transnationale religiøse udsyn og postwestfalske religionsform. Et eksempel på, hvor svært det er at klassificere migrantkirker inden for modellen, er den filippinske kirke Jesus Is Lord, der blev godkendt

10 Sagen om Fouroozandeh og Church of Love har også åbnet op for en folkekirkelig debat om selve proceduren for godkendelse af migrantkirker som valgmenigheder (Garde 2014). 
som trossamfund i Danmark i 2013 (Familiestyrelsen 2014). Kirken er oprindelig startet i Filippinerne i 1978 og har en meget aktiv politisk profil i hjemlandet, hvor den har været involveret i politiske reformbevægelser i 1970erne og 80erne (Cornelio 2013, 41). Jesus Is Lord er i stor vækst både i Filippinerne og i resten af verden som følge af dens filippinske medlemmers transnationale arbejdsmigration. Teologisk set er den karismatisk evangelisk i sin kristendomsforståelse med en neo-pentekostal profil (Pew Forum 2006). I Danmark benyttes kirken hovedsageligt af filippinske au pairs, som er i Danmark på to-årige kontrakter og rejser videre til næste au pair job i Europa, før de til sidst vender tilbage til Filippinerne. Denne transnationale au pair profil fører til, at Jesus Is Lord er en kirke, hvis menighed lever i konstant bevægelse mellem landegrænserne, men med en national orientering mod Filippinerne. Jesus Is Lord bliver derfor snarere en udvidet del af den filippinske religionsmodel end den danske, ikke ulig de danske kirker i udlandet (se Margit Warburgs artikel i dette temanummer). Dog må man sige, at den enkelte au pairs transnationale tilværelse muliggør en postwestfalsk tilgang til medlemskab. I Danmark deltager flere filippinere både i messer i den katolske kirke på Amager og i karismatiske møder i Jesus Is Lord. ${ }^{11}$ En au pair fortalte mig, at Jesus Is Lord er god at være en del af, når man arbejder som au pair, men at hun ville vende tilbage til sin lokale kirke, når hun senere ville være mere permanent i Filippinerne. ${ }^{12}$ Det eksklusive medlemskab er ikke vigtigt, fordi kirker som Jesus Is Lord arbejder mod have et produkt målrettet migranter, der er på det globale religiøse marked i en begrænset periode.

Dermed vender vi os nu mod den del af Beyers postwestfalske religionsbegreb, der beskriver forandringer på institutionsniveau, dvs. religionssystemets modellering over andre systemer. Jesus Is Lord kan på mange måder siges at modellere sig over det økonomiske system, fordi det er så produkt- og markedsorienteret en kirke. I de nordiske lande er det tilpasset et bestemt segment; filippinske kvinder mellem 20-30 år, der arbejder som au pairs. ${ }^{13}$ Da mere eller mindre hele menigheden udskiftes jævnligt, ser de lokale kirker det som deres opgave at hjælpe folk i deres midlertidige ophold og inden for kirken uddanne dem til tro evangeliske kristne i deres videre færd. ${ }^{14}$ Jesus Is Lord kan findes i næsten alle de lande, hvor filippinere migrerer for at arbejde. Det betyder, at den enkelte au pair hele tiden rejser til den samme kirke, selvom den nationale kontekst skifter. Kirken bliver også et netværksskabende fællesskab målrettet au pair-branchen, hvor au pairs tager hen for at netværke med andre au pairs. Kirken holder sig i live ved at have et målrettet produkt, som det kan tilbyde på tværs af landegrænser. Derfor repræsenterer denne migrantkirke også en postwestfalsk modellering over det økonomiske funktionssystem. Men der er forskel

11 I Filippinerne er $81 \%$ af befolkningen katolikker, hvilket betyder at størstedelen af de au pairs, som kommer til Danmark er opvokset som katolikker (Bouma, Ling \& Pratt 2010, 92)

12 Notater fra besøg og interviews i Jesus is Lord Church 10.-17. september 2014.

13 Der er også mandlige au pairs, men da deres antal er forsvindende lille, har jeg valgt ikke at tage dem med her.

14 Notater fra besøg og interviews i Jesus is Lord Church 10.-17. september 2014. 
på, hvordan kirkens modellering over det økonomiske system påvirker på forskellige niveauer. På individniveau er der en del au pairs, som både benytter de evangeliske kirker og den katolske kirke alt efter, hvad den enkelte kirke tilbyder. På institutionsniveau konkurrerer kirkerne mod hinanden på et globalt marked.

For en kirke som Jesus Is Lord og dens menighed af filippinske au pairs giver det ikke mening at blive en del af den danske religionsmodels kerne, da dens profil er så specifikt karismatisk evangelisk og orienteringen filippinsk. Men samtidig er den en kirke i vækst, der befinder sig i den danske religionsmodels grænseflade som godkendt trossamfund. Kirken låner bl.a. den folkekirkelige Alle Helgens Kirke på Amager, København, hver søndag eftermiddag til tre timers gudstjeneste, og er også derfor et eksempel på samarbejde mellem folkekirke og migrantkirke. Jesus Is Lord giver os et eksempel på den mangetydige placering migrantkirker udgør i den danske religionsmodel. Den er både en del af den danske model og den filippinske model, samtidig med at kirken med sin produktbevidsthed er målrettet filippinske arbejdsmigranter, der er meget transnationale i deres arbejdsrutiner.

\section{Konklusion}

Migrantkirker er til stede i den danske religionsmodel i teologiske debatter, kirkelige bygninger og juridiske bestemmelser, ligesom de historisk har udfordret og udvidet den danske religionsmodel.

De nye migrantkirker er placeret i den danske religionsmodels grænseflade som kristne minoritetsreligioner, men nogle er i bevægelse ind mod modellens kerne som tilfældet er med Church of Love. I den anden ende af spektret har vi Jesus Is Lord, der med sin karismatiske kristendom og specifikke transnationale - og filippinske produktorientering vil blive ved med at være i den danske religionsmodels grænseflade. Migrantkirkerne er en mangefacetteret størrelse, der på flere måder udfordrer det westfalske religionsbegreb, som praktiseres i den danske religionsmodels kerne.

\section{LITTERATUR}

Adogame, Afe

2010 "Pentecostal and Charismatic Movements in a Global Perspective", in: Bryan Turner, ed., Blackwell Companion to the Sociology of Religion, Wiley-Blackwell, Oxford, 498-518.

Adogame, Afe \& Shobana Shankar

2013 "Introduction: Exploring new frontiers in global religious dynamics", in: Afe Adogame \& Shobana Shankar, eds., Religion on the Move! New Dynamics of Religious Expansion in a Globalizing World, Brill, Leiden, 1-17.

Arendt, Niels Henrik

2009 "Bevæggrund for projektet og hovedtrækkene i resultatet", in: Folkekirken og migrantmenigheder. En publikation på baggrund af indlæg ved konference på Vartov 7. januar 2009, Folkekirkens mellemkirkelige råd, Frederiksberg. 
Asad, Talal

2003 Formations of the Secular - Christianity, Islam, Modernity, Stanford University Press, New York.

Bekendtgørelse af lov om bestyrelse og brug af folkekirkens kirker mm.

2014 https://www.retsinformation.dk/forms/R0710.aspx?id=162459 (set 18.04.2014).

Berlingske Tidende

2013 "Biskop vil stoppe dåb af omvendte muslimer", 06.12.2013.

Beyer, Peter

2012 "Socially Engaged Religion in a Post-Westphalian Global Context: Remodeling the Secular/Religious Distinction", Sociology of Religion 73 (2), 109-129.

Blückert, Kjell

2000 The Church as Nation. A Study of Ecclesiology and Nationhood, European University Studies, Peter Lang, Berlin.

Borup, Jørn

2011 Religion, kultur og integration. Vietnameserne i Danmark, Museum Tusculanum Press, København.

Bouma, Gary D. Rod Ling \& Douglas Pratt

2010 Religious Diversity in Southeast Asia and the Pacific, National Case Studies, Springer, London.

Casanova, José

2010 "Immigration and the New Religious Pluralism: A European Union/United States Comparison", in: Thomas Banchoff, ed., Democracy and the New Religious Pluralism, Oxford University Press, Oxford, 60-83.

Castles, Stephen \& Mark J. Miller

2003 The Age of Migration: International Population Movements in the Modern World, Palgrave-Macmillan, Basingstoke.

Christoffersen, Lisbet, Hans Raun Iversen, Niels Kærgård \& Margit Warburg

2012 "Den danske religionsmodel. Indledning", in: Lisbet Christoffersen et al., eds., Fremtidens danske religionsmodel, Forlaget Anis, København, 23-39.

Connor, Philip

2014 Immigrant Faith. Patterns of Immigrant Religion in the United States, Canada, and Western Europe, New York University Press, New York.

Cornelio, Jayeel Serrano

2013 "Religious Freedom in the Philippines: From Legalities to Lived experience", The Review of Faith E International Affairs 11 (2), 36-45.

Drejergaard, Kresten

2011a “Ordinationstale for Massoud Fouroozandeh", http://www.fyensstift.dk/biskoppen/landemode/ tidligere-biskop/ordination/migrantpraest/ (set 18.04.2014)

2011b “Biskoppens nytårshilsen 2011/12", http://www.fyensstift.dk/blogs/kresten-drejergaard/biskoppensnytaarshilsen/ (set 18.04.2014)

Dyremose, Charlotte

2009 "Det kristne fællesskab forpligter", in: Folkekirken og migrantmenigheder, En publikation på baggrund af indlæg ved konference på Vartov 7. januar 2009, Folkekirkens mellemkirkelige råd, Frederiksberg.

Ebaugh, Helen Rose

2003 "Religion and the New Immigrants", in: Michele Dillon, ed., Handbook of the Sociology of Religion, Cambridge University Press, Cambridge, 225-239.

Familiestyrelsen

2014 "Anerkendte og godkendte trossamfund og menigheder", http://www.familiestyrelsen.dk/samliv/ trossamfund/anerkendteoggodkendtetrossamfundogmenigheder/ (set 21.04.2014)

Folkekirkens mellemkirkelige Råd

2014 http://www.interchurch.dk/kontakt/raadets-medlemmer/ (set 19.04.2014). 
Garde, Kristine

2014 "En migrantmenigheds trange vej ind i folkekirken", Kristeligt Dagblad 11.09.2014.

Hirschmann, Charles

2004 "The Role of Religion in the Origins and Adaptation of Immigrant Groups in the United States", International Migration Review 38 (3), 1206-1233.

Hvithamar, Annika

2007 “De kristne ortodokse menigheder i Danmark: Tal fra diasporaen”, in: Margit Warburg \& Brian Arly Jacobsen, eds., Tørre tal om troen. Religionsdemografi i det 21. århundrede, Forlaget Univers, Højbjerg, 110-126.

Iversen, Hans Raun

2013 “Nye Menighedsformer i folkekirken”, in: Bent Berring-Nielsen et al., eds., Den mangfoldige kirke. Menighedsformer i Danmark. Ny Mission 24, 60-71.

Jacobsen, Brian Arly

2008 Religion som fremmedhed $i$ dansk politik, en sammenligning af italesættelser af jøder i Rigsdagstidende 190345 og muslimer i Folketingstidende 1967-2005, upubliceret ph.d.- afhandling, Københavns Universitet.

Kirkernes Integrationstjeneste

2014 http://www.kit-danmark.dk/dk/omkit/vedtaegter/ (set 19.04.2014).

Kivisto, Peter

2014 "Reframing Immigrant Religious Organizations and Practices", Nordic Journal of Religion and Society 27 (1), 1-17.

Koning, Daniëlle

2013 "New Dynamics of Christian Expansion: Boundary Crossing in the Mission of Immigrant Churches in the Netherlands" in: Afe Adogame \& Shobana Shankar, eds., Religion on the Move! New Dynamics of Religious Expansion in a Globalizing World, Brill, Leiden, 342-357.

Krarup de Medeiros, Elisabeth

2009 "Generelle tendenser i migrantmenigheder", http://www.migrantmenigheder.dk/44739/44898/ (set 20.04.2014).

Kristeligt Dagblad

2013 “Biskopper: Man kan ikke både være frikirke- og folkekirkepræst", 07.12.2013.

Landsforeningen af Menighedsråd

2014 "Høringssvar vedrørende forslag til lov om ændring af lov om bestyrelse og brug af folkekirkens kirker m.m. og lov om folkekirkens kirkebygninger og kirkegårde" (høringssvar afgivet d. 16. september 2013), http://www.menighedsraad.dk/fileadmin/user_upload/Dokumenter/2012/ H\%C3\%B8ringssvar/2013/Kirkers_brug.pdf (set 16.09.2014).

Lund, Hans Henrik

2009 "Migrantmenigheder - en farverig mosaik", http://www.migrantmenigheder.dk/44739/44897/ (set 15.04.2014).

Martikainen, Tuomas

2009 "Religious Diversity beyond the Cosmopolis: Immigration and the Religious Field in the City of Turku, Finland", Religion 39, 176-81.

Migrantmenigheder

2009a http://www.migrantmenigheder.dk/44739/44945/44953/ (set 21.04.2014).

2009b http://www.migrantmenigheder.dk/44746/44942/ (set 15.11.2014).

Nielsen, Marie Vejrup

2014 "Kristendom i udkanten af Danmark - globale tendenser i en lokal sammenhæng", in: Religion $i$ Danmark 2014, Aarhus Universitet, http://samtidsreligion.au.dk/religion-i-danmark/2013/intro/ (set 21.04.2014).

Pew Forum

2006 Spirit and Power. A 10 Country Survey of Pentecostals, The Pew Forum on Religion \& Public Life, 
Washington, http://www.pewforum.org/files/2006/10/pentecostals-08.pdf (set 16.11.2014).

Robertson, Roland

1995 "Glocalization: Time-Space and Homogeneity-Heterogeneity", in: Mike Featherstone, Scott Lash \& Roland Robertson, eds,, Global Modernities, London, Sage.

Sareen, Manu

2012 "Lovforslag om valgret i pastorater med flere sogne samt udvidet adgang til brug af kirker", http://www.km.dk/index.php?id=22\&no_cache=1\&print=1(set 16.11.2014).

Sørensen, Jørgen Skov

2009 "Migrantmenigheder i Danmark", in: Religion i Danmark 2009, Aarhus, Center for SamtidsReligion, http://samtidsreligion.au.dk/religion-i-danmark/rel-aarbog09/jss/ (set 20.04.2014).

Tværkulturelt Center

2014 Migrantmenigheder i Danmark. Oversigt april 2014. Upubliceret publikation fra Tværkulturelt Center.

Valgmenighedsloven

2014 https://www.retsinformation.dk/Forms/R0710.aspx?id=152429 (set 21.04.2014).

Vedtægt for Folkekirkens Migrantarbejde

2011 http://www.fyensstift.dk/fileadmin/fyensstift/PDF/Migrantprojekt.PDF (set 18.04.2014).

Warner, Stephen R.

1998 "Immigration and religious communities in the United States", in: Stephen R. Warner \& Judith G. Wittner, eds., Gatherings in Diaspora: Religious Communities and the New Immigration, Temple University Press, Philadelphia, 3-34.

Währisch-Oblau, Claudia

2009 The Missionary Self-Perception of Pentecoastal/Charismatic Church Leaders from the Global South in Europe. Bringing Back the Gospel, Leiden, Brill

Astrid Krabbe Trolle, videnskabelig assistent, cand. mag. Afdeling for Systematisk Teologi, Københavns Universitet 
